\title{
Geological and Structural Positions of Ore Fields and Deposits of Ore Area Auminzatau- Beltau
}

\author{
Fathullayeva Zilola, Usmonova Shakhodat, Aripova Mavjuda, Alimov Maruf
}

\begin{abstract}
Review the examination geologic-structural position gold mine location of Auminzatau-Beltau is mine of district Central of Kizilkum. Everybody location placement in seven structural of position formations north-lasterly, northwesterly, full-scale systems fractures and theirs is combine Find inosreslarch recommended using how criterion search gold mines manifestation.
\end{abstract}

Keyword: Useful fossil the golden, region, golden, structural position, textbook, arrangement mountain the gold.

\section{INTRODUCTION}

The problem of learning positions of endogenous ore fields and deposits occurred in 80ths of last century. This period is characterized by huge successes in researching geological and structural contidion of positioning of hydrothermal deposits of Tian-Shan. Geological material received during the research allowed to set wide diapason of indications and factors of controlling mineralization, which is considered as the basis on setting positions and systematics of ore areas and deposits in accordance with their positioning in geological area taking into account natural environment, structural and tectonic elements and magmatic formations and etc.

Ore deposits are characterized by different groups of signs: direct and indirect signs specified "before", "during" and "after" the ore formation process. This is reported in many groupings of ore objects, but they differ according to the principle of classification. Thus, the first group based on types of tectonic deformations of host rocks. Many classifications focus on ranging ore objects according to structural types: neutral (folded), fractured, contact, combined, where structural and tectonic factors of controlling formation of ore field and deposit are considered as foundation for them.

Issue on geological and structural positions of ore fields and deposits arose in the end of the last century, when resources of surface and near-surface deposits were depleted and it became necessary to search and explore flanks of

Revised Manuscript Received on October 15, 2019.

Fathullayeva Zilola, teacher at the geology department at the National University of Uzbekistan named after Mirzo Ulugbek, Tashkent, Uzbekistan

Usmonova Shakhodat, teacher at the geology department at the National University of Uzbekistan named after Mirzo Ulugbek, Tashkent, Uzbekistan(E-mail: sh.usmonova@nuu.uz)

Aripova Mavjuda,. teacherk at the geology department at the National University of Uzbekistan named after Mirzo Ulugbek, Tashkent, Uzbekistan(E-mail: m.aripova@nuu.uz)

Alimov Maruf. teacherk at the geology department at the National University of Uzbekistan named after Mirzo Ulugbek, Tashkent, Uzbekistan(E-mail: m.alimov@nuu.uz) systematics of ore fields and deposits. The issue of geological and structural positions can be determined as

deeper aquifers of deposits, which are already known and in the process of work.

First works focused on the study of geological and structural positions of ore fields and deposits of Middle Asia were carried out by V.A.Korolev (1983) and Kh.A.Akbarov (1975, 2006). In their studies positions of ore objects in Middle Asia were determined in accordance with following features:

1.Host rocks. Structural and morphological features of positions depend on the content and structure of ores, and their physical and mechanical features.

2.Belonging to structural level. Paleozoic level of Middle Asia is folded as follows: lower Paleozoic layer shales and terrigenous rocks; medium Paleozoic layer calcareous and calcareous-terrigenous rocks; upper Paleozoic layer - volcanogenic and terrigenous rocks. PrePaleozoic structural level is folded by: metamorphized terrigenous, calcareous rocks, acid intrusive complexes.

3. Belonging to folded structures. Majority of ore fields and deposits are classified as folded structures, in their apical parts as zones of longitudinal fractures, as sections of interface of longitudinal and transversal fault structures, which complicate structural-tectonic fold texture.

4. Belonging to fault structures. Ore fields and deposits are formed in single fractures, in their bend areas, in interface and intersection zones of fractures, in the structural plumages of fractures, in blocks between couple fractures and in zones of complication of folded structures in the form of longitudinal and interface fractures. 5. Relation to intrusive formations. Hydrothermal ore fields usually coincide with contact and exo-contact zones. Intrusive structures are formed inside intrusives under the impact of fractural structures; formed above intrusive area; in some distance from intrusive where fractures take place.

Based on these principles Kh.A. Akbarov (2006, 2011) determined structural positions of lead-zinc deposits of Middle Asia according to their structural belonging. In other words, main attention is focused on positions in geological and structural types of ore fields of deposits in folded, fractured, contact and combined types.

However, further research of geological and structural conditions of formation and position of mineralization indicates that in majority of cases the process of formations of ore objects take place in folded and fracture structures, mainly in fracture structures, which determine positions of 
objects in geological area. Until now the problem of study of structural positions of gold mineralization objects located in Western Uzbekistan, particular, in Auminzatau-Beltau mining region was not an object of deeper investigation.

Several works can be found thus now, where geological and structural positions of gold mineralization objects of Western Uzbekistan, particularly Auminzatau-Beltau, are defined in short form. These works vary not only in method of research of geological and structural conditions of mineralization positioning, but also in results of investigations despite the fact that during the determination of positions the focus was kept on folded and fracture structures. Solution of this problem allows us to carry out effective prospecting and exploitation in narrow geological area in perspective and structural positions and investigations (table No.1).

\section{Systematics Of Gold Mineralization Deposits Of Central-Kizilkum Region}

(Atlas Of Ore Fields And Deposits Of Western Uzbekistan Was Used While Drawing The Table (Gold-Silver) i. T. Tashpulatov, M.N.yuldashev. T.SH.shayakubov. 1987y.)

(Table No.1)

\begin{tabular}{|c|c|c|c|c|c|c|c|}
\hline № & $\begin{array}{l}\text { Name of } \\
\text { object }\end{array}$ & $\begin{array}{l}\text { Primary } \\
\text { and } \\
\text { secondary } \\
\text { useful } \\
\text { component } \\
\text { s }\end{array}$ & $\begin{array}{c}\text { Pore } \\
\text { formation } \\
\text { belonging }\end{array}$ & $\begin{array}{l}\text { Mineral } \\
\text { type of } \\
\text { ores }\end{array}$ & $\begin{array}{c}\text { Morphology of } \\
\text { mineralization } \\
\text { process }\end{array}$ & $\begin{array}{c}\text { Geological and } \\
\text { positions of th }\end{array}$ & $\begin{array}{l}\text { tructural } \\
\text { object }\end{array}$ \\
\hline 1 & $\begin{array}{l}\text { High } \\
\text { voltage }\end{array}$ & $\begin{array}{l}\text { Silver } \\
\text { (gold, } \\
\text { tellurium) }\end{array}$ & $\begin{array}{l}\text { Gold-silver - } \\
\text { ore }\end{array}$ & $\begin{array}{l}\text { Silver- } \\
\text { sulphide } \\
\text { salt } \\
\text { сульфасол } \\
\text { ьный }\end{array}$ & $\begin{array}{l}\text { Mineralized zones, } \\
\text { zones of } \\
\text { development of } \\
\text { quartz strands, } \\
\text { cross-shaped, } \\
\text { falciform and lens- } \\
\text { shaped ore bodies }\end{array}$ & $\begin{array}{l}\text { Intersection joints } \\
\text { of fractures of } \\
\text { northern-north- } \\
\text { western and sub- } \\
\text { latitudinal } \\
\text { directions in } \\
\text { terrigenous rocks of } \\
\text { besapan suite }\left(\mathrm{R}_{3} ?\right)\end{array}$ & \\
\hline 2 & Daugiztau & Gold & $\begin{array}{l}\text { Pyrite- } \\
\text { arsenopyrite- } \\
\text { gold } \\
\text { mineralizatio } \\
\text { n }\end{array}$ & $\begin{array}{l}\text { Gold - } \\
\text { arsenopyrit } \\
\text { e-pyrite }\end{array}$ & $\begin{array}{l}\text { Mineralized zones, } \\
\text { ore bodies in the } \\
\text { form of lens- } \\
\text { shaped, ribbon-like } \\
\text { and steeply- } \\
\text { dipping basins }\end{array}$ & $\begin{array}{l}\text { Removing zones } \\
\text { and fractures of } \\
\text { north-western } \\
\text { direction within the } \\
\text { territory of } \\
\text { development of } \\
\text { besapan suite }\left(\mathrm{R}_{3} \text { ?) }\right.\end{array}$ & \\
\hline 3 & Muruntau & $\begin{array}{l}\text { Gold } \\
\text { (silver, } \\
\text { wolfram) }\end{array}$ & $\begin{array}{l}\text { Rare metal- } \\
\text { gold } \\
\text { mineralizatio } \\
n\end{array}$ & $\begin{array}{l}\text { Gold - } \\
\text { (arsenopyri } \\
\text { te-pyrite), } \\
\text { scheelite }\end{array}$ & $\begin{array}{l}\text { Ore basins in the } \\
\text { form of echelon } \\
\text { folded sub-tabular } \\
\text { stockworks and } \\
\text { transversal core } \\
\text { strands }\end{array}$ & $\begin{array}{l}\text { Removing zones of } \\
\text { sub-latitudinal and } \\
\text { north-eastern } \\
\text { fractures within the } \\
\text { area of development } \\
\text { terrigenous rocks of } \\
\text { besapan suite }\left(\mathrm{R}_{3} \text { ?) }\right. \\
\text { and tasgazkan suite } \\
\left(\mathrm{R}_{3} ?\right)\end{array}$ & \\
\hline 4 & $\begin{array}{l}\text { Amantayta } \\
\mathrm{u}\end{array}$ & Gold & $\begin{array}{l}\text { Pyrite- } \\
\text { arsenopyrite- } \\
\text { gold } \\
\text { mineralizatio } \\
\text { n }\end{array}$ & $\begin{array}{l}\text { Gold- } \\
\text { arsenopyrit } \\
\text { e pyrite }\end{array}$ & $\begin{array}{l}\text { Mineralized zones } \\
\text { with strand-shaped } \\
\text { and lens-shaped } \\
\text { steeply-dipping } \\
\text { ore bodies }\end{array}$ & $\begin{array}{l}\text { Removing zones of } \\
\text { north-eastern and } \\
\text { sub-meridional } \\
\text { fractures within the } \\
\text { area of development } \\
\text { of terrigeneous } \\
\text { layer of besapan } \\
\text { suite }\left(\mathrm{R}_{3} \text { ?) }\right.\end{array}$ & \\
\hline
\end{tabular}

As it was noted by A.V.Korolev, deformation of host rocks is one of main factors of primary conditions, which lead to entrance of ore rocks with further ore disposal. (A.V. Korolev, 1983). According to him, deformation of rocks occurs under impact of different forces, but endogenous forces generate tensity of the Earth's crust are crucial in this process. In forecasting and prospecting endogenous hydrothermal deposits, while learning patterns of their formation study of tectonic tenses involved in the formation of ore-bearing structures and interrelated with deformation is given preliminary attention. 
The staff of the Institute of Mineral Resources (M.K.Turapov, B.O.Jonibekov, N.Yu.Dulabova) have been researching tectonic tenses and deformation of areas of gold mineralization in Central Kizilkum, including AuminzatauBeltau ore region, which is under research process. The aim of their investigation is the result of investigation of formation patterns of gold mineralization transfer to closed territories by mezzo- The purpose of their research is to transform the results of research into the formation patterns of gold ore objects in the region and the conditions for placing gold mineralization in them to closed areas of the Mezo-Cenozoic formations in order to assess their prospects for gold.

Analysis of the results of experimental tectonic-physical investigation of gold mineralization processes in Auminzatau-Beltau region, carried out by M.K.Turapov, B.O.Jonibekov, N.Yu.Dulabova and others showed, that tectonic-physical processes of almost all processes occurred with gold of Auminzatau is determined by their relation to zones of extremely weak and weak voltage. Tectonic and physical positions of mineralization is exception. In Nadyojnoye, odinochnoye, South Uzunsay, Uzunsay and Bijankora positions are defined by fields of moderate size of tectonic stresses.

Almost all type of gold mineralization in Beltau are connected with fields of weak and extremely weak voltages. These facts determine their tectonic and physical positions.

As it was noted by many researchers, block construction is typical for Central Kizilkum, particularly for investigated territory.

Reconstruction of geodynamics of mineralization period $\left(\mathrm{C}_{3}-\mathrm{P}_{1}\right)$ carried out by B.O. Jonibekov and others showed that geodynamical circumstances of this period is characterized by activity of fracture structures, which are considered as borderlines of tectonic block. In this connection activity of faults caused replacement of blocks towards to each other. Analysis of this information allowed to determine geodynamical circumstances of gold mineralization areas with more certainty.

In Auminzatau geodynamic condition of gold mineralization areas is mainly conditioned upon

(the table was drawn using materials of M.K.Turapov, N.Yu. Dulabova, B.O.Jonibekiv, Yu.I. Paramonova and others)

\begin{tabular}{|l|l|l|l|l|l|l|l|}
\hline $\begin{array}{l}\text { № } \\
\text { o/ } \\
\mathrm{n}\end{array}$ & $\begin{array}{l}\text { Name of the } \\
\text { object }\end{array}$ & \begin{tabular}{l} 
Positions \\
\cline { 2 - 7 } \\
logic \\
al
\end{tabular} & Structural & $\begin{array}{l}\text { Tectonic and } \\
\text { physical }\end{array}$ & $\begin{array}{l}\text { Geodynamical } \\
\text { al }\end{array}$ \\
\hline 1 & 2 & 3 & 4 & 5 & 6 & 7 \\
\hline Auminzatau & Uzunkuduk & $\mathrm{S}_{1} \mathrm{bs}_{4}$ & $\begin{array}{l}\text { Interfacial zone of } \\
\text { north-western and } \\
\text { north-eastern fault } \\
\text { and v-shaped } \\
\text { structures }\end{array}$ & $\begin{array}{c}\text { Zone of } \\
\text { extremely } \\
\text { weak voltages }\end{array}$ & $\begin{array}{l}\text { Movement of the } \\
\text { block to the east }\end{array}$ & $-0.5-1.0$ \\
\hline 1 & & &
\end{tabular}

replacement of blocks, where objects are placed and activity of north-western ore controlling faults. During the period of ore mineralization geodynamical position of gold occurrence was conditioned by vertical-horizontal movements on north-eastern and north-western faults.

The reason for paying particular attention to geodynamics of gold mineralization areas is that movement through faults, replacement of blocks are interrelated with rock deformation and their tensity.

В этом аспекте немаловажную роль играют и физические особенности вмещающей среды, т.е. геофизические параметры.

Analyzing information of regional geophysical anomalies, results made by N.Yu. Dulabova on Bukantau and B.O.Janibekov on Auminzatau and Beltau about relation of majority of gold mineralization objects to the strip between minimal values of positive and negative geophysical anomalies. This is typical for all numbered gold mineralization processes of Beltau.

So, taking into account methodological recommendations of A.V.Korolev (1983) and Kh.A.Akbarov (2006) we made an effort to determine positions of gold mineralization in Auminzatau-Beltau ore region in regard to tectonic stresses, deformation of rocks, geodynamics of the ore formation period and geophysical anomalies. All these physical aspects of ore region are interrelated. During the process of ore mineralization, they represented particular qualities, which are recommended for using as forecasting criteria and prospecting signs of ore mineralization within the territory of Auminzatau-Baltau ore region. (Table No.2)

\section{MATERIALS AND METHODS}

Methods of researching geological and structural conditions of positioning endogenous ore fields and deposits worked out by A.V. Korolev and P.A.Shekhtman contain the basis of this dissertation. At that attention is focused on method of learning fracture structures. Structural positions of ore objects are defined with method of analogies, and their perspective is valued in order to search for ore mineralization.

\section{Positions of gold occurrence in Auminzatau-Beltau ore region}


Geological and Structural Positions of Ore Fields and Deposits of Ore Area Auminzatau-Beltau

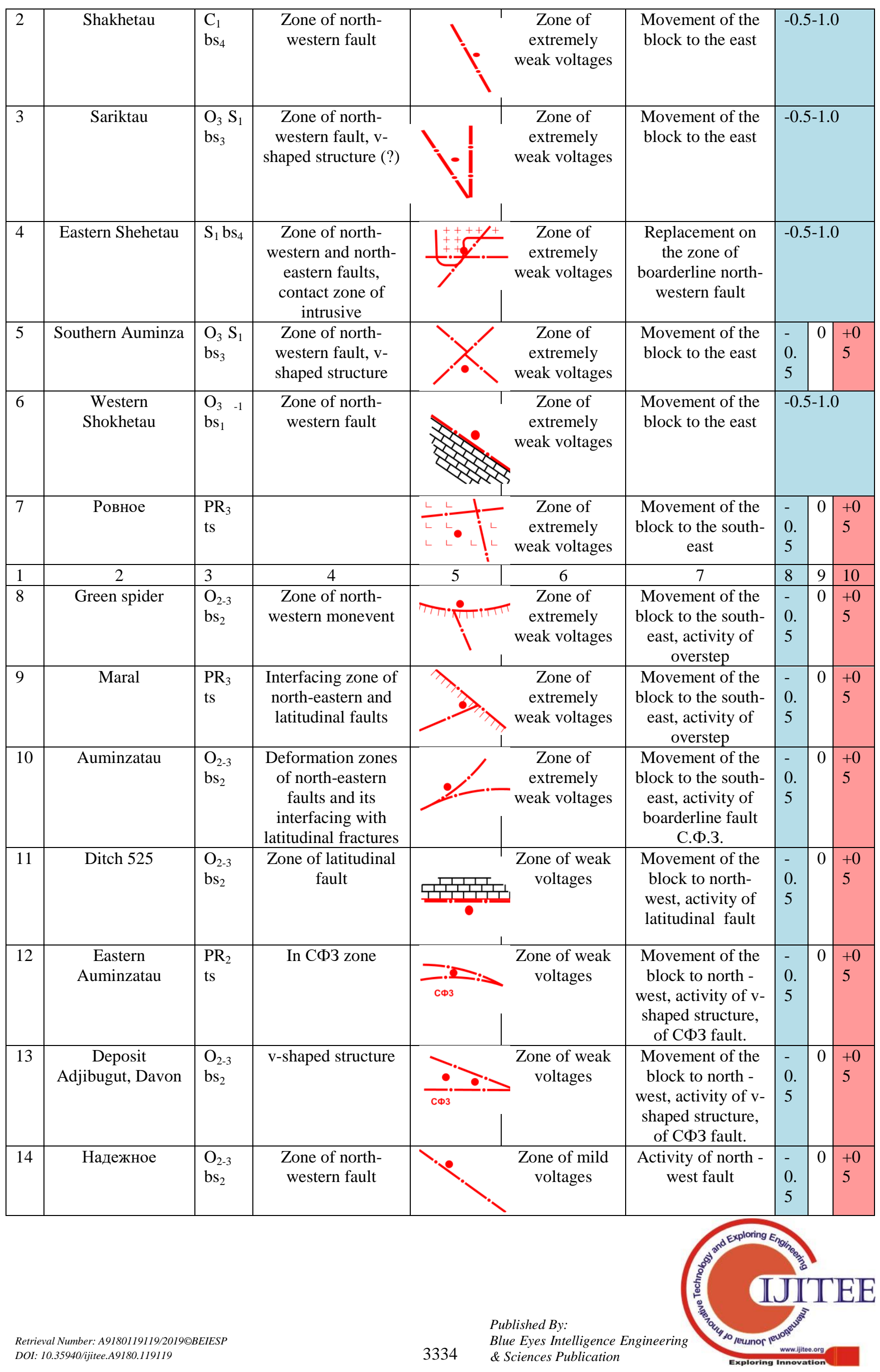




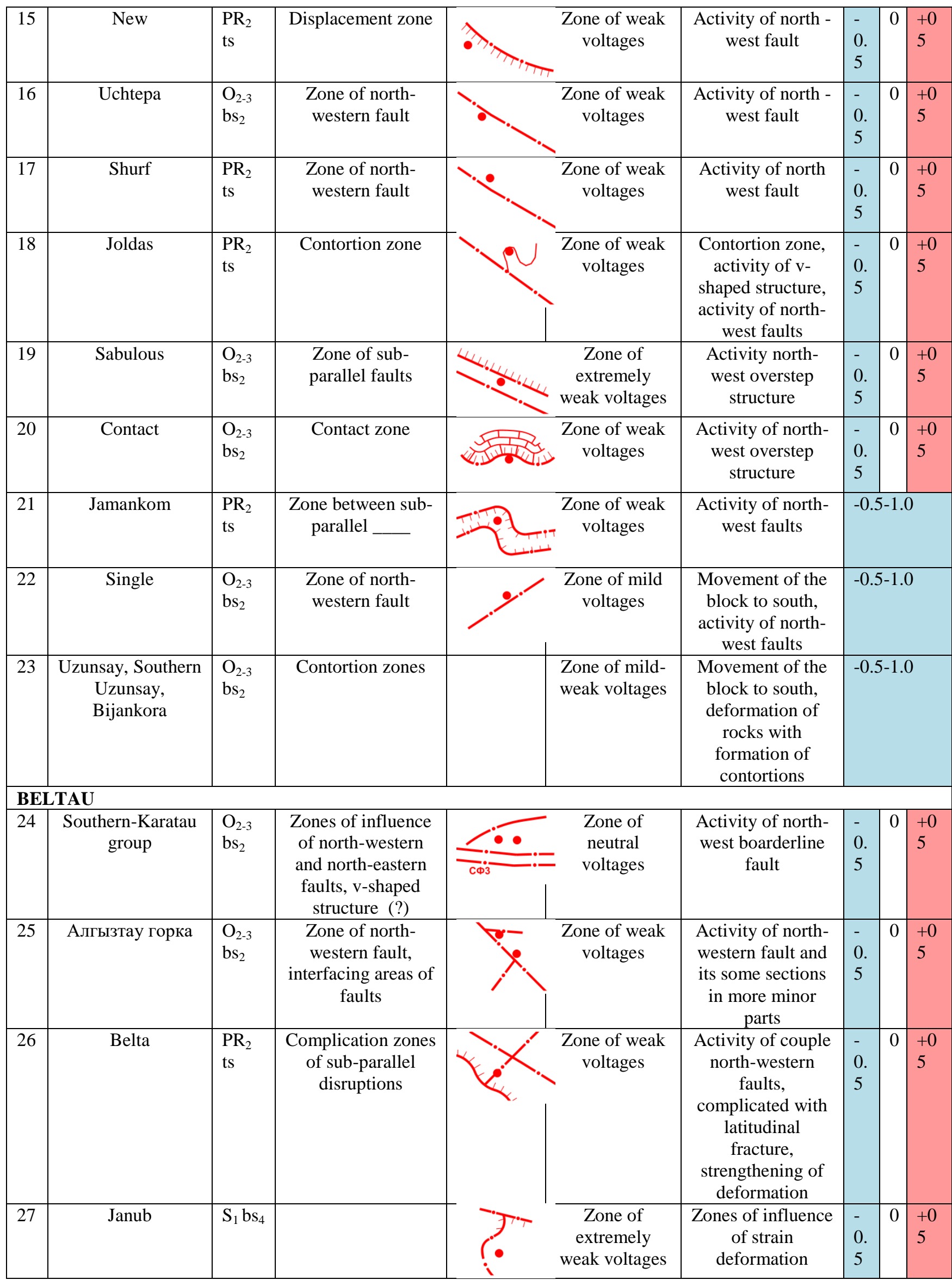


Geological and Structural Positions of Ore Fields and Deposits of Ore Area Auminzatau-Beltau

\begin{tabular}{|c|c|c|c|c|c|c|c|c|c|}
\hline 28 & Deposit Saribatir & $\begin{array}{l}\mathrm{O}_{3-} \mathrm{S}_{1} \\
\mathrm{bs}_{3}\end{array}$ & $\begin{array}{l}\text { Zone of north- } \\
\text { western fault, v- } \\
\text { shaped structure of } \\
\text { interfacing north- } \\
\text { western and } \\
\text { latitudinal faults }\end{array}$ & 8 & $\begin{array}{c}\text { Zone of } \\
\text { extremely } \\
\text { weak voltages }\end{array}$ & $\begin{array}{c}\text { Zones of influence } \\
\text { of strain } \\
\text { deformation, } \\
\text { activity of v- } \\
\text { shaped structure }\end{array}$ & $\begin{array}{l}- \\
0 . \\
5\end{array}$ & 0 & $\begin{array}{l}+0 \\
5\end{array}$ \\
\hline 29 & $\begin{array}{c}\text { Deposit } \\
\text { Tazgazkan }\end{array}$ & $\begin{array}{l}\mathrm{O}_{3-} \mathrm{S}_{1} \\
\mathrm{bs}_{3}\end{array}$ & $\begin{array}{c}\text { Zone of north- } \\
\text { western fault }\end{array}$ & & $\begin{array}{c}\text { Zone of } \\
\text { extremely } \\
\text { weak voltages }\end{array}$ & $\begin{array}{l}\text { Activity of north- } \\
\text { western faults, } \\
\text { and v-shaped } \\
\text { structure }\end{array}$ & $\begin{array}{l}- \\
0 . \\
5\end{array}$ & 0 & $\begin{array}{l}+0 \\
5\end{array}$ \\
\hline 30 & Deposit Yasaul & $\begin{array}{l}\mathrm{O}_{3-} \mathrm{S}_{1} \\
\mathrm{bs}_{3}\end{array}$ & $\begin{array}{c}\text { Zone of north- } \\
\text { western fault v- } \\
\text { shaped structure } \\
\text { due to interfacing } \\
\text { of north-western } \\
\text { faults }\end{array}$ & & $\begin{array}{c}\text { Zone of } \\
\text { extremely } \\
\text { weak voltages }\end{array}$ & $\begin{array}{l}\text { Activity of north- } \\
\text { eastern faults, and } \\
\text { v-shaped structure }\end{array}$ & $\begin{array}{l}- \\
0 . \\
5\end{array}$ & 0 & $\begin{array}{l}+0 \\
5\end{array}$ \\
\hline 31 & $\begin{array}{c}\text { High-voltage } \mathrm{Au}- \\
\text { Ag deposit }\end{array}$ & $\mathrm{S}_{1} \mathrm{bs}_{4}$ & $\begin{array}{c}\text { Fault zone of } \\
\text { Daugiztau fracture, } \\
\text { interfacing zone } \\
\text { with north-eastern } \\
\text { fault, v-shaped } \\
\text { structure }\end{array}$ & & $\begin{array}{c}\text { Zone of } \\
\text { extremely } \\
\text { weak voltages }\end{array}$ & $\begin{array}{l}\text { Activity of north- } \\
\text { eastern faults, and } \\
\text { deep Daritas } \\
\text { structure }\end{array}$ & $\begin{array}{l}- \\
0 . \\
5\end{array}$ & 0 & $\begin{array}{l}+0 \\
5\end{array}$ \\
\hline 32 & Deposit Daugiz & $\mathrm{S}_{1} \mathrm{bs}_{4}$ & $\begin{array}{c}\text { Fault zone of } \\
\text { Daugiztau fracture, } \\
\text { interfacing zone } \\
\text { with north-eastern } \\
\text { fault, v-shaped } \\
\text { structure }\end{array}$ & & $\begin{array}{c}\text { Zone of } \\
\text { neutralization } \\
\text { of voltages }\end{array}$ & $\begin{array}{l}\text { Activity of north- } \\
\text { eastern faults, and } \\
\text { deep Daritas } \\
\text { structure }\end{array}$ & $\begin{array}{l}- \\
0 . \\
5\end{array}$ & 0 & $\begin{array}{l}+0 \\
5\end{array}$ \\
\hline 33 & $\begin{array}{l}\text { Deposit Asaukak, } \\
\text { Northern Ausakak }\end{array}$ & $\mathrm{S}_{1} \mathrm{bs}_{4}$ & $\begin{array}{c}\text { Fault zone of } \\
\text { Daugiztau fracture, } \\
\text { interfacing zone of } \\
\text { C2 with north- } \\
\text { eastern disruption, } \\
\text { v-shaped structure }\end{array}$ & & $\begin{array}{c}\text { Zone of } \\
\text { neutralization } \\
\text { of voltages }\end{array}$ & $\begin{array}{l}\text { Activity of north- } \\
\text { eastern faults, and } \\
\text { deep Daritas } \\
\text { structure of zone } \\
\text { of influence }\end{array}$ & $\begin{array}{l}- \\
0 . \\
5\end{array}$ & 0 & $\begin{array}{l}+0 \\
5\end{array}$ \\
\hline 34 & North-eastern & $\mathrm{S}_{1} \mathrm{bs}_{4}$ & $\begin{array}{l}\text { Zone of north- } \\
\text { eastern fault }\end{array}$ & & $\begin{array}{c}\text { Zone of } \\
\text { neutralization } \\
\text { of voltages }\end{array}$ & $\begin{array}{l}\text { Activity of north- } \\
\text { eastern fault }\end{array}$ & $\begin{array}{l}- \\
0 . \\
5\end{array}$ & 0 & $\begin{array}{l}+0 \\
5\end{array}$ \\
\hline 35 & Roadside & $\mathrm{S}_{1} \mathrm{bs}_{4}$ & $\begin{array}{l}\text { Zone of north- } \\
\text { eastern fault }\end{array}$ & & $\begin{array}{c}\text { Zone of } \\
\text { extremely } \\
\text { weak voltages }\end{array}$ & $\begin{array}{l}\text { Activity of north- } \\
\text { eastern fault, } \\
\text { zones of } \\
\text { intersection with } \\
\text { north-western } \\
\text { fractures }\end{array}$ & $\begin{array}{l}- \\
0 . \\
5\end{array}$ & 0 & $\begin{array}{l}+0 \\
5\end{array}$ \\
\hline
\end{tabular}




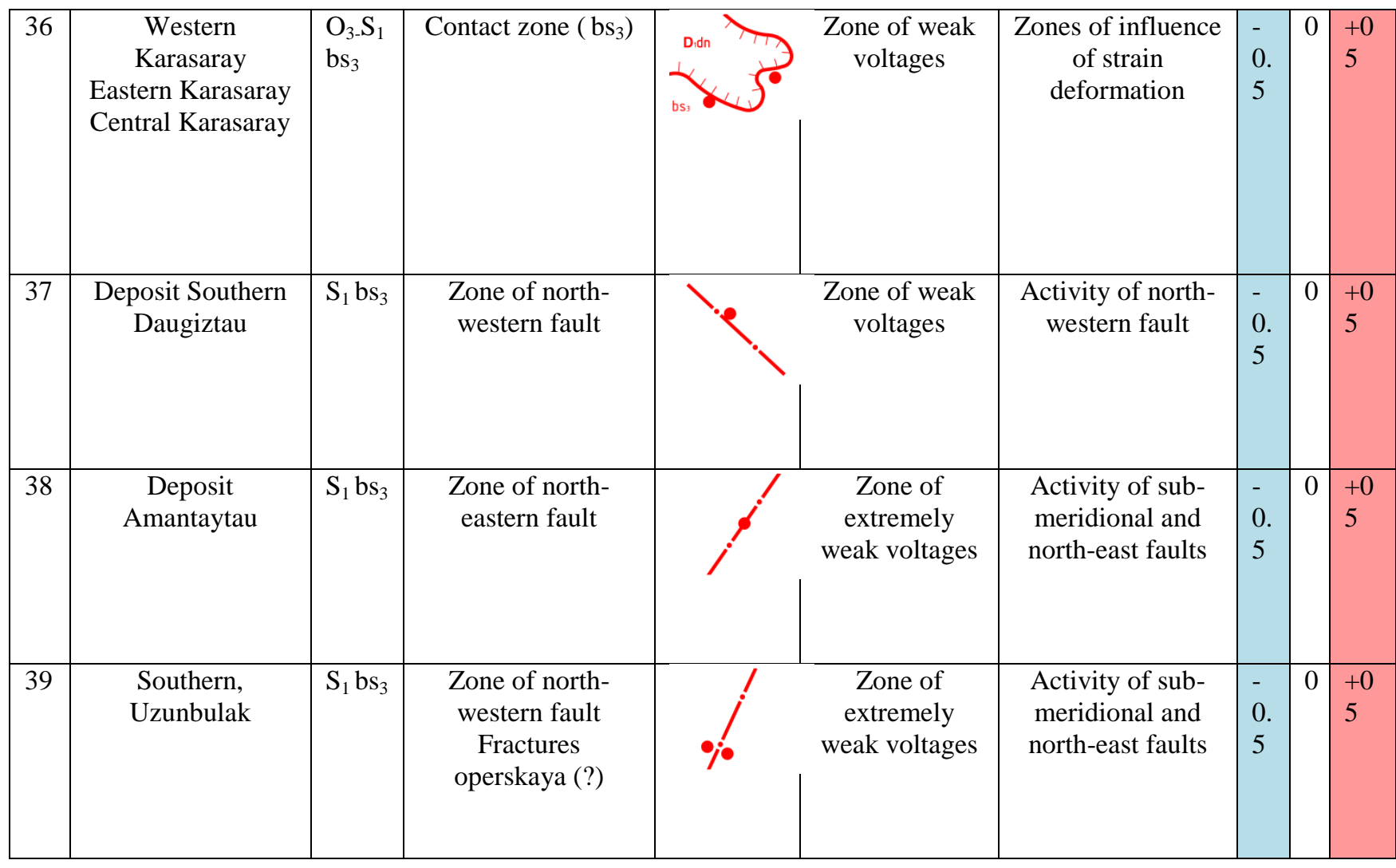

\section{RESULTS AND DISCUSSION}

During the investigation geological and structural conditions of formation and placement of deposits and ore occurrences of gold of Auminzatau-Beltau ore region was on the focus. Special attention was given to fracture structures, which controlled formation and spatial positioning of ore objects. In this gold mineralization occurrences lower Paleozoic terrigenous formations of Besapan suite play the role of ore containing rocks. In regard to folded structures almost all gold mineralization occurrences of the region relate to walls of anticlinal structures, which are complicated with large north-western, north-eastern and sub-latitudinal faults. Zones of their interfacing and intersection with transversal deep faults were conductive for circulation of fluid hydrothermal solutions and formation of gold mineralization objects.

Analysis of structural conditions of formation of gold mineralization occurrences of Beltau showed wider diapason of structural elements which controlled ore disposal process. All occurrences of gold formed in seven structural positions, which are connected with the zones of north-western, north-eastern faults with their areas of deformation, interface and intersection. Zones of subparallel faults, and v-shaped structures formed due to intersections and interfacing of sub-meridional and northeastern fractures were also prospective structural positions for gold mineralization processes. Enumerated structural positions control all gold occurrence processes in Beltau. Wide diapason of structural elements, which controlled formation of deposits and gold mineralization processes in Beltau leads us to believe that ore process proceeded at tectonic activity of ore region, in unstable geodynamical condition, when fault structures were active. Their activity lead to formation of faults at open faces and interfaces and intersections at open knots. All these process in complexity with geological environment (terrigenous formation) establish particular conditions, which enabled gold mineralization process in following positions.

In geological structure of Central Kizilkum different formations of rocks, which are characterized by various lithological content which in combination of regional and local tectonic magmatic elements and products caused diversity of geological and structural types of ore fields and deposits of golds and other metals in their position in geological area. Learning patterns of formation, defining factors of controlling mineralization and their geological and structural classification allowed Kh.A.Akbarov and others to conclude that position of ore object is crucial criterion for prospection.

Position of object in particular geological structure is one of crucial criteria, which allows to set off particular area in perspective fields for discovering ore mineralization. Morphological peculiarities of structural positions allow us to forecast morphology and spatial separation of endogenous mineralization. Taking this fact into consideration structural positions of gold mineralization of investigated territory can be set off with certainty and recommended for implementation as criteria at prospection in Central Kizilkum. Improvement of effectiveness of prospection may be achieved also in combination of positions of objects, in regard to folded and fracture disruption. Position of gold mineralization in folded structures in the entire territory of region is determined by relation to walls of anticlina structures, which are often preserved in fragments. This fact

Published By: 
reduces areas of prospection significantly, which is reflected in the results of prospection.

\section{CONCLUSIONS}

Carried out investigations show that mineralization of gold of the region has precisely defined structural position. Morphological peculiarities of ore bodies and their spatial position towards to geological formations allow to make conclusion that structural factor or structural position plays crucial role in positioning of mineralization, and geological environment, its lithological content and physical and mechanical features are main reasons for establishment and development of fracture structures, formation of structural positions.

\section{REFERENCES}

1. Korolev A.V., Shekhtman P.A. "Structural conditions of positioning after magmatic ores" M; Nedra.,1965, p.506.

2. Korolev V.A. "Structural types of ore fields and deposits of Central Asia" M; Nedra. 1983. p.215.

3. Akbarov Kh.A. and others "Theoretical and methodological aspects of local forecasting of endogenous mineralization" Tashkent, TashSTU, 2011, p.455.

4. Akbarov Kh.A., and others. Geological and structural types of polymetallic ore fields and deposits in Central Asia and some issues of their search and exploration. Tashkent: The science, 1975. p.200.

5. Akbarov Kh.A. Structural typification of polymetallic ore fields and deposits of various genesis for the development of initial models in experiments // Experiment and modeling in structure-forming processes of ore genesis // Tp. Institute of Geol. and geophysis. SB USSR Academy of Sciences. - Novosibirsk; The science, 1976. - Rele. 293. pp.178-189.

6. Golovanov I.M. Ore deposits of Uzbekistan. Tashkent, IMR, 2001.

7. I.T.Toshpulatov, M.N. Yuldashev, T.Sh.Shayakubov. (1987). Atlas of ore fields and deposits of western Uzbekistan (gold-silver).

8. Turapov M.K.(1990). and others. Modelling structures of one of objects of Eastern Kurama. Naukovadumka, p.89.

9. Janibekov B.O. (2017) and others. Structural positions and geodynamical conditions of gold mineralization occurrence in Auminzatau-Beltau ore region. Gorniy vestnik No.3, 80.

10. Dulapova N.Yu. (2010) "Patterns of gold mineralization positioning in mountain structures of Bukantau and estimation of perspectives of surrounding closed territories" Abstract of dissertation for candidate degree, 24. 